\title{
The role of the New Zealand Grassland Association in communicating science to the grassland industry: history, lessons and directions
}

\author{
M.J. CASEY, D.R. STEVENS, D.J. MOOT, D.F. CHAPMAN, G.A. KERR, \\ W. McG. KING, A. MEIKLE, L. COPLAND, A.D. BLACK and J.I. KERSLAKE \\ New Zealand Grassland Association, 11 Montrose St, Mosgiel, New Zealand \\ eo@grassland.org.nz
}

\section{Introduction}

This is the 80th edition of the NZGA annual publication and the 87 th year since the Association was formed in 1931. Much has changed over that time, including some substantial changes to the way that science is funded and communicated to farmers and the wider industry. It is timely to reflect on the history and progress of the Association towards meeting its principal objective: "To foster progress in all matters relating to grassland". Over the years, many NZGA Presidents have noted issues and challenges faced by the Association. Reading through these papers reminds us that many of the questions and challenges faced in the industry today and by the Association are not new. For example, Banfield (1976) noted the loss of land to forestry as a significant threat. This process has been reversed recently, and with forestry conversion to pasture being a major focus at the Wairakei conference in 2007. Recent Government decisions to plant more trees potentially returns us to that 1975 situation where the subsequent lack of employment associated with locking up land for forestry was noted.

Green (2005) identified hill-country as in need of research, as "increasing pressure is being placed on our highly fertile and easily cultivable flat lands for crop production". This was the focus of our special symposium in 2016 with the aim of stimulating research activity in this sector.

This paper follows up the recent analysis of the history and impact of the NZGA throughout its 87 years started by David Stevens President's address to the Association in 2017 and the Ray Brougham Memorial Lecture series delivered by Derrick Moot in 2017. Papers about the Association have been published by various authors over the decades (Saxby 1955; Woodfield \& Charlton 1989; Green 2005) and these provide a resource that traces the progress of the NZGA.

The key objectives of this paper are to update the history of the Association and identify some of the highlights and trends since our last review.

\section{Aims and objectives of the NZGA}

Thurston (1978) described the establishment of NZGA in August 1931 with the inaugural conference at
Palmerston North and the adoption of a constitution. A preliminary meeting had been held in January of that year, called by Alfred Cockayne, then Assistant Director-General of Agriculture. This first meeting was attended by 21 people representing the Department of Agriculture, DSIR, Massey University, Lincoln College, The Cawthron Institute and some fertiliser companies. This meeting recommended that an Association be formed with Cockayne saying "Let us have a grassland caucus which will dominate grassland research and improvement".

The objectives of the Association were based on the premise of "the betterment of research, investigation, demonstration or instruction in grassland management generally" as stated at that inaugural meeting. These have essentially remained unchanged over the life of the Association, and are encapsulated in the Association's constitution:

1. To foster progress in all matters relating to grassland

2. To encourage collaboration between all persons connected with grassland

3. To hold conferences, meetings, lectures and field days, and to make publications.

In 2010, the Association adopted the tagline: "Fuelled by Science, and Tempered by Experience", from the mission statement developed by the NZGA Executive under Richard Green (2005). This highlights the comments by Cockayne (1947) "... that there should be the closest possible and intimate relationship of the grassland farmer, the extension worker and the research worker, all working to the same end, the betterment of the NZ grassland..."

White (1974) noted opportunities for new publications to complement the Proceedings, changes to conferences to include symposia, and the potential to expand our influence into the Pacific Islands. The latter has not been acted upon probably due to the large difference between temperate and tropical agriculture. Nonetheless, delegates from the Americas and Australia, where climatic conditions and management are similar in some regions, have frequently attended the conference.

Toxopeus (1984) identified the ebb and flow of regional enthusiasm with the rotation of the 
conference around New Zealand. He suggested that the answer to these issues lay with members making sure the Association remains seen and heard across New Zealand. This continues to be an issue with the Association often not returning to a region for 30 years. As conference attendance often exceeds 300 delegates we may find smaller centres unable to host this number.

Chu (1987) suggested that the main medium of paper presentation be as a poster, with panel discussions based around keynote papers. He suggested that field days should focus on local issues and a proceedings of the talks be published. Posters were replaced with thumbnails in 2010 as part of our largest ever conference at Lincoln University, when we joined with the Australian and New Zealand Agronomy Associations. Many presenters of thumbnails are becoming experts at focused messaging.

As we entered our 75th year, Green (2005) outlined a path forward for the Association towards a profitable and professional organisation. He pointed to the need for consolidation to truly reflect paying membership, a live strategy, an open and robust accounting system and a relevant agenda that continued to attract great conference attendances. He also noted that the core objectives of the Association as set up in 1931 were unchanged.

The aims of the Association are regularly tested by the NZGA Executive. This paper will be used as a precursor to ongoing reviews of the strategy and activities of the Grassland Association.

\section{Membership}

The membership of the Association has grown since the meetings called by Cockayne in early 1931 .

Membership grew rapidly in the 1980 s to over 1500 (Woodfield \& Charlton 1989), but has settled to around 900 -1000 members since 2010 (Table 1).

Membership has varied more widely within years than the June 30th data indicates (M.J. Casey, Executive Office, pers. comm.). This reflects the policy decision taken before 2010 to remove members 2 years in arrears of membership dues. Retirement, resignation, lost contact details and a more fluid job market all impact on paying member numbers.

The proportion of farmers, researchers, and agribusiness has remained relatively constant over time (Table 1). Watkin (1973) observed that membership was made up of around $40 \%$ farmers, $30 \%$ advisory and $25 \%$ scientists, which is broadly consistent with recent numbers if the assumption is made that the 1972 definition of "Advisory" should now include "Agribusiness". The 2018 data, however, does reveal a decline in the number of farmers, the reason for which is unknown. This is a concern, but it remains to be seen whether it is within the normal range of variability or a more permanent change in membership.

Also of note is the difference between conference attendance and Association membership observed by Saxby (1955). This suggests farmers value the information within the Proceedings (now Journal) and other publications, but do not always attend conference.

Conferences are increasingly being used by agribusiness companies (Table 1) as part of their employees' professional development. Their presence has helped stabilise attendance at the annual conference over the last 10 years or so to $300-350$ delegates.

The gender balance of the Association has improved over the 87 years, and since the first female presented a paper at conference in 1958 . We celebrated the first female President, Jacqueline Rowarth, in 2011. Currently, it is not possible to analyse the membership data to determine the gender balance, but women are now well represented amongst the scientists, student presenters and rural professionals.

Strong sponsorship in support of the annual conference has enabled the Association to keep its

Table 1 Sector composition (\%) of membership, and total number of members (updated from Woodfield \& Charlton 1989; Green 2005).

\begin{tabular}{lcccccccc}
\hline & $\mathbf{1 9 5 0}$ & $\mathbf{1 9 6 9}$ & $\mathbf{1 9 7 6}$ & $\mathbf{1 9 8 1}$ & $\mathbf{1 9 8 6}$ & $\mathbf{2 0 0 0}$ & $\mathbf{2 0 0 5}$ & $\mathbf{2 0 1 8 ^ { * }}$ \\
\hline Farmers & 33 & 46 & 59 & 52 & 50 & 51 & 46 & 33 \\
Research, University and Advisory & 45 & 37 & 25 & 21 & 25 & 25 & 26 & 27 \\
Advisory & & & $16^{\star *}$ & 14 & 11 & $* * *$ & $* * *$ & 11 \\
Agribusiness & 12 & 16 & 9 & 12 & 9 & 19 & 26 & 22 \\
Students & 0 & 0 & 0 & 0 & 4 & 4 & 0 & 2 \\
Other & 10 & 1 & 1 & 1 & 1 & 1 & 7 \\
\hline Total number & 268 & 540 & 500 & 1022 & 1450 & 1138 & 1246 & 906 \\
\hline
\end{tabular}

*2018 data to March.

${ }^{\star *}$ Advisory category created.

${ }^{\star \star \star}$ Advisory grouped with Agribusiness. 
registration cost at one of the lowest levels for any comparable conference in New Zealand. Over the years the number of organisations (including research institutions) willing to support NZGA has slowly grown to a key group of around 15 established national businesses. A key question the Executive consider regularly is whether sponsors fit our tagline "Fuelled by Science and Tempered by Experience".

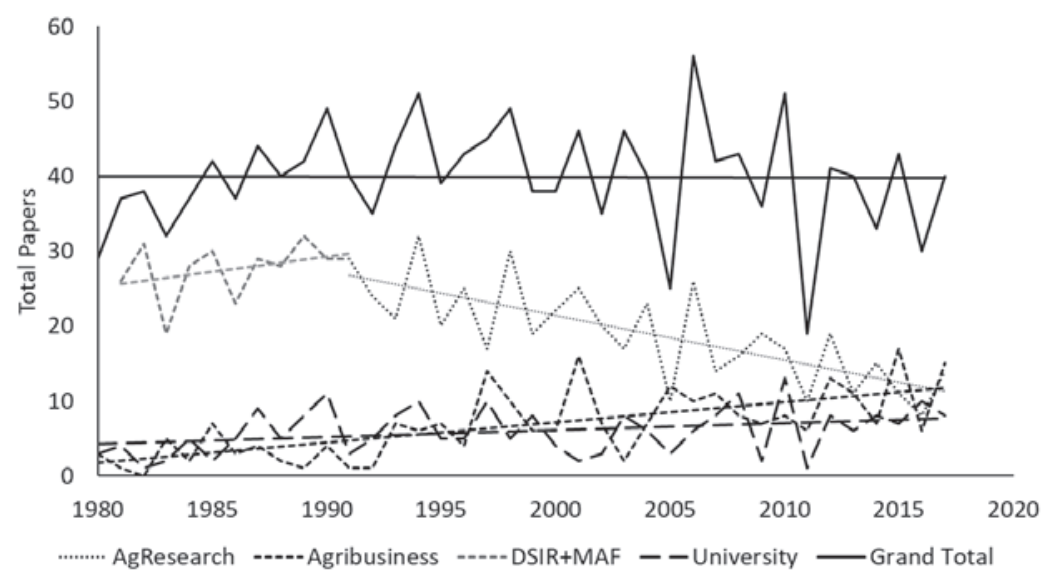

Figure 1 Source of papers offered at each NZGA Conference
The support of these businesses extends beyond direct financial sponsorship, as they also contribute staff to Local Conference Organisation Committees and the Executive.

\section{Communications}

\section{Publishing}

The Journal of New Zealand Grasslands (previously the Proceedings of the New Zealand Grassland Association) is an important source of practical science for the grassland industry. More than 2100 papers have been published since 1931 (Table 2). The number of papers published each decade increased to a peak during the 1990s, with high numbers in each of the last three decades. There has, however, been a recent decline in the proportion of papers from research and extension and an increase from the agribusiness sector. The decline in the number of papers from public sector scientists reflects policy changes and science reforms in the 1990s. These aimed to increase industry contributions to science with some success in the agriculture sector.
The Proceedings/Journal has consistently comprised about 40 papers but the composition of authors has changed (Figure 1). The decline in papers offered from AgResearch - the major research provider to the pastoral industries - remains a concern. DairyNZ began publishing in 1997 and latterly, seed and fertiliser companies have offered their results for publication, with these groups being represented as Agribusiness in Figure 1.

A feature of the Proceedings/Journal has been the dedication of referees to rigorously maintain the standards and independence of the publication. This has sometimes led to difficult decisions for the editor when papers are rejected, but is consistent with the standard expected of peer-reviewed journals. A feature of the last 5 years has been the advent of online submission of papers and their processing by referees. The Association decided to make all papers freely available online in 2011 to support our obligation to inform the wider community. This also ensures authors receive maximum exposure of their work as an incentive to

Table 2 Presentation of papers at annual conferences, by sector (updated from Woodfield \& Charlton 1989).

\begin{tabular}{|c|c|c|c|c|c|c|c|c|c|c|c|c|c|c|c|c|}
\hline & \multicolumn{2}{|c|}{$1931-38$} & \multicolumn{2}{|c|}{$1947-59$} & \multicolumn{2}{|c|}{$1960-69$} & \multicolumn{2}{|c|}{$1970-79$} & \multicolumn{2}{|c|}{$1980-89$} & \multicolumn{2}{|c|}{$1990-99$} & \multicolumn{2}{|c|}{ 2000-09 } & \multicolumn{2}{|c|}{ 2010-17 } \\
\hline & No. & $\%$ & No & $\%$ & No. & $\%$ & No. & $\%$ & No. & $\%$ & No & $\%$ & No & $\%$ & No & $\%$ \\
\hline Farmers & 15 & 8 & 15 & 10 & 24 & 15 & 22 & 12 & 28 & 7 & 32 & 7 & 19 & 5 & 15 & 4 \\
\hline Research/Extension* & 108 & 59 & 107 & 69 & 106 & 65 & 133 & 69 & 260 & 69 & 253 & 58 & 197 & 50 & 117 & 39 \\
\hline University & 39 & 21 & 12 & 8 & 19 & 12 & 18 & 10 & 44 & 12 & 70 & 16 & 53 & 13 & 61 & 21 \\
\hline Agribusiness ${ }^{* *}$ & 8 & 5 & 6 & 4 & 4 & 2 & 3 & 2 & 28 & 7 & 60 & 14 & 86 & 22 & 83 & 28 \\
\hline Others & 12 & 7 & 15 & 9 & 10 & 6 & 13 & 7 & 18 & 5 & 18 & 4 & 41 & 10 & 21 & 7 \\
\hline Total & 182 & & 155 & & 163 & & 189 & & 378 & & 433 & & 355 & & 297 & \\
\hline
\end{tabular}




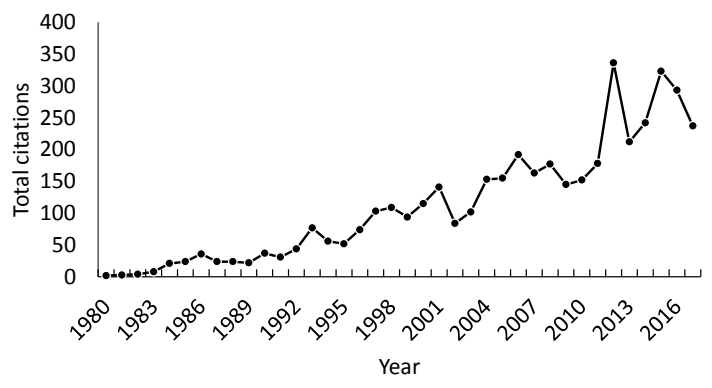

Figure 2 Annual total number of citations of articles published in the Proceedings of the New Zealand Grassland Association and Grassland Research and Practice Series since 1980.

continue to publish and present papers at conference. The Proceedings/Journal is indexed in the CAB index, which now sits within the Web of Science (WoS) database. A search of WoS in November 2017 returned 1167 papers published since 1980 that had been cited a total of 4693 times for an average of 4.02 citations/ paper. This citation rate over the same period is similar to our sister publication, the Proceedings of the New Zealand Society of Animal Production (of 3.8 citations/ paper). Citations have been growing steadily, peaking at 336 in 2012 (Figure 2). Not all volumes appear to be listed in WoS, so total citations are likely to be greater that those reported in the 2017 search.

\section{Website}

The Association developed its first website in the early 2000s and a major upgrade was completed mid2011. The number of individual users has risen from 6980 in 2012 to 7628 in the last 12 months (Figure $3)$. The individual page views have also risen from 27823 to 29871 , over the same period. Usage rises during the academic year indicating access by students, identified from website access through Massey and Lincoln University servers, and towards conference in November as authors' access papers. The most accessed sections of the website are the Proceedings followed by the conference registration and event details. It follows that this open access allows students to see the current and future work published by NZGA. In turn, some of these students are now attending conference and looking for their own opportunities to publish.

\section{Executive}

The Executive continues to support conferences in the regions, alternating between North and South Island. The hard work of the Local Organising Committee (LOC) and the local support they raise continues to be a key factor in the success of the conference. Many of the members of the LOC come from NZGA sponsors and do this with the support of their employers, but the

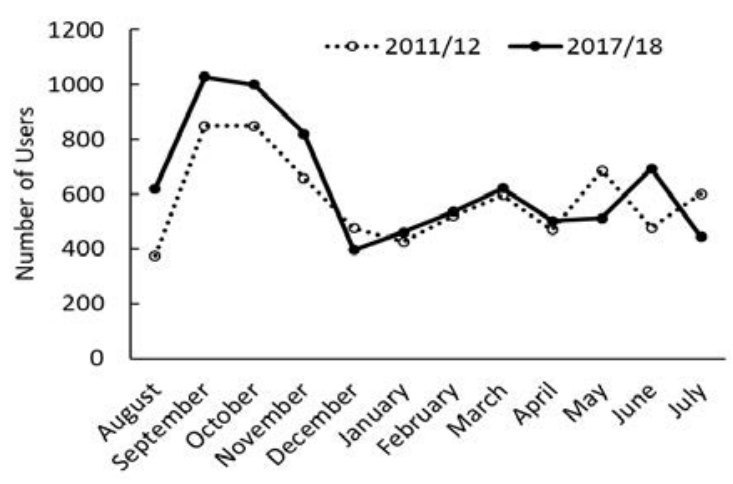

Figure 3 Comparison of views of the NZ Grassland Association website when it was first launched (2011-2012) and this year (2017-2018).

importance of the time effectively donated by farmers on the LOC cannot be underestimated.

The NZGA annual conference continues to be a blend of a regional event and a national conference. Each conference has a theme that expresses the local flavour supported by invited papers, expert regional papers, farmer papers and field trips. The conference also fulfils a national role, attracting papers on new pastoral research from throughout New Zealand and, on occasions, from overseas.

While conferences may not have changed substantially from those described by Woodfield \& Charlton (1989), there is still room for innovation. Workshops have been used effectively (e.g. Lincoln 2010, Masterton 2015) and facilitated discussion sessions using tools such as 'Slido' for submission of audience questions via smart-phones proved popular (Whanganui 2017). Both the Levy and Brougham Orations are now recorded and made available on the NZGA website. Some memorable and important contributions have been made available to a wider audience this way (e.g. Holmes $2016 \mathrm{https} / / \mathrm{www}$. youtube.com/watch? $\mathrm{v}=8 \mathrm{O} 1 \mathrm{yr} 9 \mathrm{VGz}-\mathrm{I})$.

\section{Administrative reform}

The past 13 years has been a period of considerable change for the Association. The need for a more professional basis was discussed by Richard Green in his Presidential address (Green 2005). The requirement to meet International Accounting Rules, the changing demographics of the industry, the changing technical landscape, research funding pressures and other trends have all had an impact.

The functions of Secretary and Treasurer were combined and contracted to Mick Calder in 2001 as a part-time role as Executive Officer. This then became a full time role with the appointment of Ross White in 2005 and has since been developed further into an Executive Office, currently split into two defined areas, 
overall and financial management.

Keeping track of the Associations finances and meeting accounting requirements is increasingly complex. The financial processes of the Association have been refined to ensure best practice management is followed and enable us to meet stringent rules under the International Accounting Regulation requirements.

The appointment of a professional Executive Officer/ Office, and the drive towards meeting International Rules has provided opportunities to maintain accurate membership inventories and develop a range of practices that meet not-for-profit standards.

Under the Presidency of David Stevens (20152017), the Executive developed specific roles for each executive member and a more detailed set of operational guidelines for the Association. The aim was to capture and document the current activities and practises as well as the institutional memory of the Association. This was considered important to put the Association on a more professional footing to secure its future.

Key actions and initiatives since 2005 include:

- Continual refinement of financial processes including application for Tax Exempt status for scientific or industrial research organisations. Adaptation to the changing rules of financial reporting

- Defining the role and responsibilities of the Executive Office

- Updating the Rules of the Association (2016) to align with actual practice. (The Executive discovered that the Association had for many years been operating with more executive members than allowed in the constitution)

- In 2012 the Executive introduced the Levy Oration to the conference programme in honour of an early pioneer of grassland science Sir Bruce Levy. This oration allows an invited speaker time to speak on the topic of his/her choosing

- Initiated the Student Travel Awards at the prompting of then President Jacqueline Rowarth in 2012. These awards support the Universities to send students to conference by funding travel, accommodation and conference registration costs

- The Proceedings of the New Zealand Grassland Association was last published in 2014 when the Association voted to change to the Journal of New Zealand Grasslands

- Updated and reprinted the 4th Edition of 'Pasture \& Forage Plants of New Zealand (Stewart et al. 2014)'. This book has become a key reference for farmers, students and agribusiness staff

- In 2011 NZGA ran the successful Pasture Persistence Symposium (Mercer 2011) in response to the challenges confronting the sector

- Similarly, the Hill Country Symposium (Thom 2016) raised the questions around the large area of New
Zealand farmland that is in the hill-country, and led to an industry Position Paper (Scrimgeour \& Sheath 2016) describing what profitable yet sustainable hillcountry looks like

- Instigation of the Online Journal System for the submission and management of the editorial process for the Journal.

These initiatives provide a platform for future success. The use of special symposia has provided opportunities for the Association, along with its partner, the New Zealand Grassland Trust, to bring particular issues to the fore for debate and potential policy and research direction.

\section{The future}

We believe the purpose of NZGA remains virtually the same as it did when formed in 1931, which is a credit to the principles of its founders.

At present the NZGA faces many challenges to the delivery of its objectives. Addressing these may require actions that are beyond what is currently considered business as usual but are critical in positioning NZGA to thrive into the future. Some of these challenges are:

- Growing the membership and key demographics, noting we have many 'older' members. Ensuring we have a solid base of farmer members to provide the practical grounding the Association needs

- Making sure what we do is appropriate for, and valued by, our members and sponsors

- Adapting to rapid change in communication norms and technologies, in social and e-media, to meet the way people like to receive information

- Increasing the professionalism of everything we do, while keeping costs at a low level, and having a solid balance sheet. Cost-saving measures may include not providing printed proceedings

- Maintaining the quality of science contributions to the Journal, as the publicly-funded science organisations suffer further erosion of public funding

- The role NZGA plays in delivering scientific integrity in an increasingly commercial world, where misinformation is increasingly normal, and where the content of media is less and less resourced is critical. Helping to give balance of science and credibility to New Zealand's pastoral industry is arguably more important than ever

- Continuing to run a relatively low cost annual conference to bring NZGA members, scientists, industry and sponsors together in a credible science forum

- Run occasional symposia, at times with other organisations, to meet more specific needs of the pastoral industry than can be addresses at the annual conference. Two of these are currently under consideration. 


\section{REFERENCES}

Banfield, G.L. 1976. Presidential address. Proceedings of the New Zealand Grassland Association 37: 1-5.

Chu, A.C.P. 1987. Presidential address. Proceedings of the New Zealand Grassland Association 48: 5-8.

Cockayne, A.H. 1947. Presidential address. Proceedings of the New Zealand Grassland Association 9: 1-7.

Green, R. 2005. Presidential address. Constant evolution to ensure a successful future. Proceedings of the New Zealand Grassland Association 67: 1-8.

Holmes, C.W. 2016. Levy Oration: New Zealand dairy farming has lost its competitive edge. Journal of New Zealand Grasslands 78: 7-10. https://www.youtube. com/watch? $\mathrm{v}=801 \mathrm{yr} 9 \mathrm{VGz}-\mathrm{I}$

Mercer, C.F. (Ed.) 2011. Pasture Persistence Symposium. Grassland Research and Practice Series 15.230 pp.

Moot, D.J. 2017. Ray Brougham Memorial Lecture, "Legumes Regenerate Pastures." https://www. youtube. $\mathrm{com} /$ watch? $\mathrm{v}=$ ZxTqDStkmeo\&t=6s

Saxby, S.H. 1955. The New Zealand Grassland Association. Proceedings of the New Zealand Grassland Association 16: 24-34.

Scrimgeour, F.; Sheath, G. 2016. Future pathways for
New Zealand hill country farming. Supplementary publication to the Hill Country Symposium Grassland Research and Practice Series $16.11 \mathrm{pp}$.

Stevens, D.R. 2018. Presidential address. Applied agricultural research, where is the future? Journal of New Zealand Grasslands 80: 7-10.

Stewart, A.; Kerr, G.; Lissaman, W.; Rowarth, J. 2014. Pasture \& Forage Plants for New Zealand. Grassland Research and Practice Series 8.139 pp.

Thom, E.R. (Ed.) 2016. Hill Country Symposium Grassland Research and Practice Series 16.341 pp.

Thurston, W.G. 1978. Opening address. Proceedings of the New Zealand Grassland Association 39: 1-4.

Toxopeus, M.R.J. 1984. Presidential address. Proceedings of the New Zealand Grassland Association 45: 5-8.

Watkin, B.R. 1973. Presidential address. Proceedings of the New Zealand Grassland Association 34: 1-7.

White, J.G. 1974. Presidential address. Proceedings of the New Zealand Grassland Association 35: 1-5.

Woodfield, D.R.; Charlton, J.F.L. 1989. NZ Grassland Association: Over 50 years of communication in grassland farming. Proceedings of the New Zealand Grassland Association 50: 55-64. 